\title{
Inability of Mitogen-activated Lymphocytes Obtained from Patients with Malignant Primary Intracranial Tumors to Express High Affinity Interleukin 2 Receptors
}

\author{
Lucinda H. Elliott, William H. Brooks, and Thomas L. Roszman \\ Department of Microbiology and Immunology, University of Kentucky Medical Center, Lexington, Kentucky 40536-0084
}

\begin{abstract}
Patients with primary malignant brain tumors manifest a variety of abnormalities in cell-mediated and humoral immunity. Diminished $\mathbf{T}$ cell reactivity has been shown in these patients to be linked to deficiencies in interleukin 2 (IL-2) production that cannot be overcome by exogenous IL-2. In this study, specific binding of radiolabeled IL-2 to PHA-stimulated lymphocytes from brain tumor patients demonstrates that the number of high affinity interleukin 2 receptors (IL-2R) is greatly reduced. FACS analysis indicates that the relative density of the p55 protein (Tac protein) is lower on the mitogen-activated lymphocytes obtained from patients than on comparably treated lymphocytes from normal individuals. These data indicate that mitogen-stimulated lymphocytes obtained from patients have fewer functional high affinity IL-2R principally because of the failure to express sufficient levels of the p55 protein for association with the p75 protein. Northern analysis of total RNA isolated from mitogen-stimulated $T$ cells from patients demonstrates normal levels of steady state mRNA, which codes for the p55 protein. Moreover, there is no defect in the postranslational processing of the primary translation product of this mRNA suggesting that normal levels of the 555 protein are produced in activated $T$ cells from patients. (J. Clin. Invest. 1990. 86:80-86.) Key words: phytohemagglutinin • interleukin $2 \cdot T$ cells $\bullet$ glioma $•$ Tac protein
\end{abstract}

\section{Introduction}

Patients with primary malignant intracranial neoplasms exhibit broad suppression of immunocompetency as manifest through a variety of in vivo and in vitro determinants (1-9). Most notably, the $\mathrm{T}$ cell hyporesponsiveness observed in these patients is a result of the failure of these cells to enter and complete the proliferative cycle when compared to comparably stimulated $\mathrm{T}$ cells obtained from normal individuals (10). This functional defect of the $T$ cell cannot be attributed to an inability to bind lectin, enhanced suppressor cell activity (11), or anomalous accessory cell function and secretion of interleukin 1, which are required for stimulation (10). However, T cells obtained from these patients do not secrete normal

Address reprint requests to Dr. Elliott, Department of Microbiology and Immunity, University of Kentucky Medical Center, 800 Rose Street, Room MS409, Lexington, KY 40536-0084.

Received for publication 6 September 1989 and in revised form 21 February 1990.

J. Clin. Invest.

(C) The American Society for Clinical Investigation, Inc.

0021-9738/90/07/0080/07 \$2.00

Volume 86, July 1990, 80-86 amounts of interleukin 2 (IL-2) after stimulation and the proliferative response cannot be restored by the addition of exogenous IL-2 (12). Collectively, these results suggest that impaired $T$ cell reactiviness results from an intrinsic defect(s) in lymphocytes obtained from patients with malignant gliomas.

Concurrent with secretion of IL-2, appropriately stimulated lymphocytes express distinct classes of receptors for this lymphokine with differing affinities and apparent function. Recent studies suggest that the functional high affinity IL-2 receptor (IL-2R) ${ }^{1}$ is composed of at least a $55-\mathrm{kD}$ polypeptide chain (p55, or Tac protein) and a $75-\mathrm{kD}$ polypeptide chain (p75) linked by noncovalent interactions (13-18). Although lymphocyte proliferation can be induced without mitogen via interaction of IL-2 with p75 (19), the formation of the high affinity IL-2R is more efficient because the concentration of IL-2 required to induce proliferation is significantly less in lymphocytes expressing high affinity IL-2R than in those $T$ cells expressing the p75 only. As a corollary, failure to assemble and express the high affinity IL-2R would result in diminished lymphocyte proliferation under physiological conditions. Investigating this possibility as an explanation for diminished $T$ cell proliferation observed in patients with malignant gliomas, we now report that lymphocytes obtained from these patients express normal levels of the p75. However, the high affinity IL-2R as well as p55 are significantly lower than normal after lectin stimulation.

\section{Methods}

Patient population. All patients received diagnosis of either glioblastoma multiforme or anaplastic astrocytoma with signs of progressive tumor growth. None received radiation, systemic steroids, or phenytoin at the time of the study. Both men and women ranged in age from 18 to $68 \mathrm{yr}$ (median, $42 \mathrm{yr}$ ). Healthy hospital employees, ranging in age from 24 to 56 years (median, $30 \mathrm{yr}$ ) served as normal controls.

Lymphocyte preparation and culture. Peripheral blood lymphocytes (PBL) were isolated by centrifugation at $400 \mathrm{~g}$ for $35 \mathrm{~min}$ on a Ficoll-Hypaque gradient (20). The lymphocyte band was collected, washed in Hanks' balanced salt solution, and adjusted to $2 \times 10^{6}$ cells/ml in RPMI 1640 medium containing $1 \%$ glutamine, nonessential amino acids, vitamins, sodium pyruvate, antibiotics, $12.5 \mathrm{mM}$ Hepes, $5 \times 10^{-5} \mathrm{M} 2$-mercaptoethanol, and $10 \%$ fetal bovine serum (FBS). Aliquots of $20 \mathrm{ml}$ were cultured in $25-\mathrm{cm}$ tissue culture flasks for $48 \mathrm{~h}$ with $50 \mu \mathrm{g} / \mathrm{ml}$ PHA-P (Difco Laboratories, Detroit, MI) at $37^{\circ} \mathrm{C}$ in a moist $5 \% \mathrm{CO}_{2}-95 \%$ air mixture. The lymphocytes were harvested at the end of this period and employed in the IL-2R assays as described below. Purified T cells were isolated by rosette formation with neuraminidase-treated sheep erythrocytes and centrifugation on a Ficoll-Hypaque gradient (7).

Radiolabeled IL-2 binding assay. A modification of the method of Robb et al. (21) was utilized to measure specific binding of ${ }^{125} \mathrm{I}$-recom-

1. Abbreviations used in this paper: IL-2R, high affinity IL-2 receptor. 
binant IL-2 (specific activity $20-40 \mu \mathrm{Ci} / \mathrm{mg}$; New England Nuclear, Boston, MA). Briefly, mitogen activated lymphocytes collected at $48 \mathrm{~h}$ after initiation of culture were incubated at $37^{\circ} \mathrm{C}$ in $50 \mathrm{ml}$ of RPMI 1640 for two 1 -h periods to remove endogenously bound IL-2. After extensive washing with $20 \mathrm{ml}$ of RPMI, $3 \times 10^{5}$ cells per tube were incubated in duplicate for $25 \mathrm{~min}$ at $37^{\circ} \mathrm{C}$ with increasing concentrations of ${ }^{125}$ I-recombinant IL-2 (rIL-2). Unlabeled rIL-2 (rIL-2 [ala]; Amgen, Thousand Oaks, CA) was added at 500-1,000-fold excess of labeled rIL-2 in duplicate tubes to determine nonspecific binding. The binding reaction was terminated by the addition of $1 \mathrm{ml}$ of ice-cold binding medium (RPMI 1640 containing 10\% FBS and $25 \mathrm{mM}$ Hepes) followed by centrifugation at $13,000 \mathrm{~g}$ for $2 \mathrm{~min}$. The cell pellets were collected and the specific bound ${ }^{125}$ I-rIL-2 determined in a gamma counter. The affinity and number of receptor sites per cell was determined by Scatchard analysis.

Quantitation of $I L-2$ receptor-positive cells and receptor density. An indirect immunofluorescence assay was employed to detect lymphocytes expressing IL-2 receptors. Lymphocytes were resuspended at a concentration of $1 \times 10^{6}$ cells in $200 \mu$ l of RPMI 1640 medium containing $10 \%$ FBS and $0.02 \%$ sodium azide. Five $\mu \mathrm{l}$ of anti-Tac monoclonal antibody (anti-Tac MAb, generously provided by Dr. Thomas Waldmann, National Institutes of Health) or an irrelevant monoclonal antibody $(\mathrm{G} 7 \mathrm{C} 10)$ directed against granulocytes (generously provided by Dr. John Thompson, University of Kentucky Medical Center) was added to the cell suspension and the mixture incubated for $30 \mathrm{~min}$ on ice. The cells were washed in PBS pH 7.2 containing $0.02 \%$ sodium azide and $10 \mu \mathrm{l}$ of a $1 / 10$ dilution of fluorescein-conjugated $\left(\mathrm{Fab}^{\prime}\right)_{2}$ fragments of goat anti-mouse IgG (Cooper Biomedical, Malvern, PA) added. After incubation on ice for $30 \mathrm{~min}$, the cells were washed in ice-cold PBS containing sodium azide, resuspended in $1 \mathrm{ml}$ of PBS and $10^{4}$ cells analyzed on a Becton-Dickinson FACS-420 (Becton-Dickinson, Sunnyvale, CA).

Northern analysis of total RNA from activated $T$ cells. Total RNA was extracted by the method of Chirgwin et al. (22) from both T cells obtained from normal individuals and patients with gliomas 16-18 h after stimulation with PHA. The RNA was electrophoresed on a $1 \%$ agarose gel containing formaldehyde, transferred to nitrocellulose, and hybridized at $42^{\circ} \mathrm{C}$ for $48 \mathrm{~h}$ with the cDNA clone pIl2R2 (generously provided by Dr. Warner C. Green, Duke University). The pIL2R2 cDNA clone, which corresponds to bases 1-937 of the human p55 IL-2R, was labeled with $\left[\alpha-{ }^{32} \mathrm{P}\right] \mathrm{dCTP}$ by random priming using an oligonucleotide labeling kit (catalog 27-9250-01; Pharmacia Fine Chemicals, Piscataway, NJ). The audioradiograms obtained from the nitrocellulose blots were analyzed using the Visage 2000 Bioimage Analyzer to determine relative levels of the various p 55 mRNA species. The blots were stripped and hybridized with a ${ }^{32} \mathrm{P}$ labeled cDNA probe for ribosomal RNA (rRNA) (generously provided by Dr. Jackie Featherstone, Louisiana State University Medical Center) to verify that similar amounts of total RNA were loaded on the gels.

Pulse-chase labeling. T cells from normal individuals and brain tumor patients were stimulated with PHA for $48 \mathrm{~h}$. The cells $\left(1 \times 10^{7}\right)$ were washed, resuspended in methionine-free RPMI 1640, and pulsed for $15 \mathrm{~min}$ at $37^{\circ} \mathrm{C}$ with $0.5 \mathrm{mCi}$ of $\left[{ }^{35} \mathrm{~S}\right]$ methionine (translation grade $800 \mathrm{Ci} / \mathrm{mmol}$, Dupont, New England Nuclear Corp., Boston, MA). Labeling was stopped by centrifugation at $400 \mathrm{~g}$ and the cell pellets were resuspended in complete RPMI containing unlabeled methionine. Culture was continued at $37^{\circ} \mathrm{C}$ in $\mathrm{CO}_{2}$ incubator for $0,15,30,60$, $120 \mathrm{~min}$, followed by extraction, immunoprecipitation with anti-Tac $\mathrm{MAb}$ and analyzed by sodium dodecyl sulfate polyacrylamide gel electrophoresis (SDS-PAGE).

Immunoprecipitation with anti-Tac MAb. The method of Davies and Brown (23) was used to extract and immunoprecipitate the precursor and final protein products of the p55 IL-2R gene. Briefly, $\left[{ }^{35} \mathrm{~S}\right]-$ methionine labeled proteins were extracted from $1 \times 10^{7}$ cells by incubation on ice for $30 \mathrm{~min}$ in $1 \mathrm{ml}$ of lysis buffer $(10 \mathrm{mM}$ Tris- $\mathrm{HCl}$ buffer, $1 \%$ NP-40, $0.5 \%$ deoxycholate, $150 \mathrm{mM} \mathrm{NaCl}, 1 \mathrm{mM}$ EDTA) containing $1 \mathrm{mg} / \mathrm{ml}$ bovine serum albumin (BSA) and $1 \mathrm{mM}$ phenylmethylsulfonyl fluoride (PMSF; Sigma Chemical Co., St. Louis, MO).
After centrifugation to remove the nuclei, the lysates were precleared with washed Staphylococcus aureus (Pansorbin; Calbiochem-Behring, San Diego, CA) and incubated overnight at $4^{\circ} \mathrm{C}$ with $10 \mu \mathrm{g} / \mathrm{ml}$ of anti-Tac MAb. An irrelevant MAb (anti-coronavirus; Chemicon, El Segundo, CA) of the same class (IgG2a) was added to control tubes. The lysates were reacted with the antibodies overnight at $4^{\circ} \mathrm{C}$, then 50 $\mu \mathrm{l}$ of washed Pansorbin was added, and the tubes were incubated at $4^{\circ} \mathrm{C}$ for $60 \mathrm{~min}$ with rotation. The antibody-Pansorbin complexes were collected by centrifugation at $13,000 \mathrm{~g}$ for $5 \mathrm{~min}$ and the pellet was washed successively in $1 \mathrm{ml}$ wash buffer-1 (lysis buffer plus $0.5 \mathrm{M}$ $\mathrm{NaCl}$ ), wash buffer-2 (lysis buffer plus $0.1 \%$ SDS) and wash buffer-3 ( $10 \mathrm{mM}$ Tris- $\mathrm{HCl}$ buffer $\mathrm{pH} 7.4,0.1 \% \mathrm{NP}-40$ ). The pellets were resuspended in $50 \mu \mathrm{l}$ of SDS sample buffer $(5 \mathrm{mM}$ Tris- $\mathrm{HCl}$ buffer $\mathrm{pH} 6.8$, $0.4 \%$ SDS, $2 \%$ glycerol, $1 \%$ 2-mercaptoethanol, $0.01 \%$ bromophenol blue) boiled for $5 \mathrm{~min}$ and centrifuged $13,000 \mathrm{~g}$ for $4 \mathrm{~min}$. The supernatants were analyzed by electrophoresis on a $10 \%$ SDS-polyacrylamide gel.

\section{Results}

Determination of the number of high affinity $I L-2 R$ on $P H A$ activated $T$ cells obtained from patients with brain tumors. We have previously reported that PHA-activated lymphocytes obtained from patients with glioblastomas contain significantly lower than normal numbers of IL-2 receptor-positive cells, as measured by indirect immunofluorescent staining with antiTac MAb (12). Since the anti-Tac MAb binds to both the functional high affinity IL-2R and the nonfunctional low affinity p55 IL-2R, it was of interest to determine which of these receptors was being affected. Binding assays were initiated using radiolabeled IL- 2 to determine the affinity and number of IL-2R expressed on PHA-activated T cells from patients with brain tumors. The comparative results of Scatchard analysis of ${ }^{125}$ I-I-L2 binding to lymphocytes from a patient with a brain tumor and a normal subject illustrate that although $\mathrm{T}$ cells obtained from patients express high-affinity IL-2R, the levels of these receptors are significantly less (threefold) than those found on lymphocytes obtained from normal individuals (Fig. 1). Indeed, high affinity IL-2R were completely un-

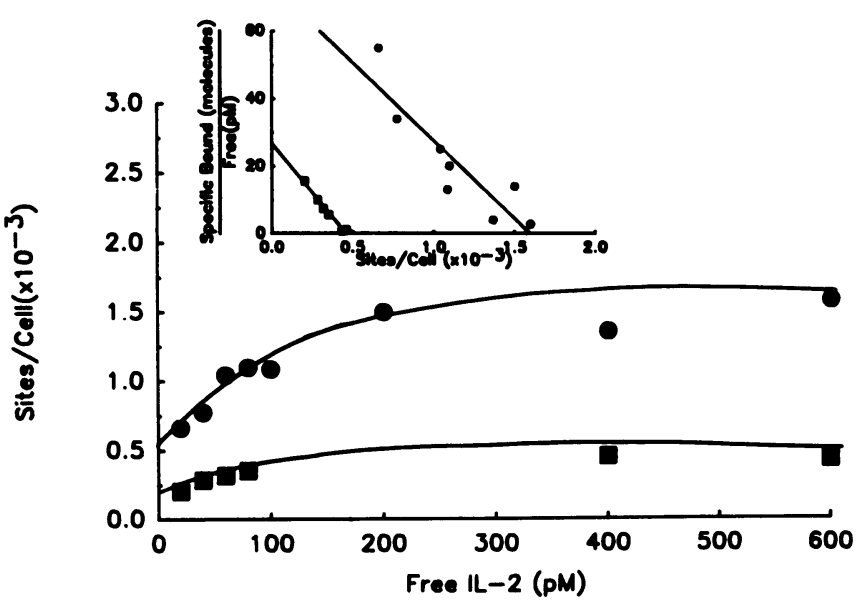

Figure 1. Typical curves for the binding of ${ }^{125} \mathrm{I}-\mathrm{IL}-2$ and Scatchard analysis (inset) of high affinity IL-2R expression on PHA-stimulated lymphocytes obtained from either a patient with a glioblastoma ( () or a normal subject $(\bullet)$. The lymphocytes were cultured with PHA for $48 \mathrm{~h}$ before performing the binding assay with ${ }^{125}$ I-IL2 as described in Methods. 
detectable on mitogen-stimulated $\mathrm{T}$ cells collected from four of seven patients (Table I).

Expression of the p55 and p75 IL-2R on PHA-activated T lymphocytes obtained from patients with brain tumors. Recent evidence reveals that the functional high affinity IL-2R is assembled by noncovalent interaction between the p55 IL-2R and the p75 IL-2R (13-17). The p55 IL-2R binds IL-2 with low affinity while the p75 IL-2R binds with intermediate affinity. Therefore, the possibility exists that an absence of either the p55 or p75 chains of the IL-2R or failure of their association in the assembly of the high-affinity IL-2R could be responsible for the diminished expression of high-affinity IL-2R on mitogen-stimulated $\mathrm{T}$ cells obtained from brain tumor patients. Scatchard analysis (Fig. 2) of ${ }^{125} \mathrm{I}-\mathrm{IL}-2$ binding to activated $\mathrm{T}$ cells from a patient illustrates that although these cells fail to express normal levels of the high affinity IL-2R (591 sites/cell, $\left.K_{\mathrm{d}} 8.3 \mathrm{pM}\right)$ they do express sufficient levels $(1,833$ sites/cell) of the p75 IL-2R that bind IL-2 with intermediate affinity $\left(K_{d} 83 \mathrm{pM}\right)$. In fact, Scatchard analysis of the data from binding assays using lymphocytes from three different patients indicate that the number of p75 IL-2R are present in excess (greater than threefold) of the high affinity IL-2 binding sites. Thus, the p75 is readily expressed on activated $T$ cells obtained from glioma patients and is available for IL-2 binding. However the relative density of p55, as determined by flow cytometry using anti-Tac MAb, is significantly lower on activated $T$ cells from patients when compared with similarly treated cells from normal individuals (Fig. 3).

Determination of steady-state levels of $\mathrm{mRNA}$ for $p 55$ in PHA-stimulated $T$ cells from patients with brain tumors. One possible explanation for the failure of PHA-activated T cells from patients to express the p55 might stem from a defect in the transcription of the gene that codes for this protein. Northern blot analyses of total RNA extracted from activated $T$ cells from normal individuals and patients (Fig. 4 and Table

Table I. Comparison of the Number of High Affinity IL-2R on Activated TCells Obtained from Normal Individuals and Patients with Brain Tumors

\begin{tabular}{lcrr}
\hline & & \multicolumn{2}{c}{ IL-2R } \\
\cline { 3 - 4 } Cell source & PHA response & $K_{\mathrm{d}}$ & $\begin{array}{c}\text { Sites } \\
\text { (molecules/cell) }\end{array}$ \\
& (\% of control)* & $p M$ & \\
Normal 1 & & 62 & 3,262 \\
Patient 1 & 53 & $\mathrm{ND}^{\ddagger}$ & 0 \\
Normal 2 & & 14 & 1,262 \\
Patient 2 & 33 & 9 & 591 \\
Normal 3 & & 22 & 1,609 \\
Patient 3 & 21 & 17 & 466 \\
Normal 4 & & 35 & 1,602 \\
Patient 4 & - & ND & 0 \\
Normal 5 & & 62 & 5,125 \\
Patient 6 & 30 & ND & 0 \\
Patient 7 & 44 & ND & 0 \\
\hline
\end{tabular}

* Percent of the normal control response of lymphocytes from patients to $10 \mu \mathrm{g} /$ well of PHA.

${ }^{\ddagger} \mathrm{ND}$, none detected.

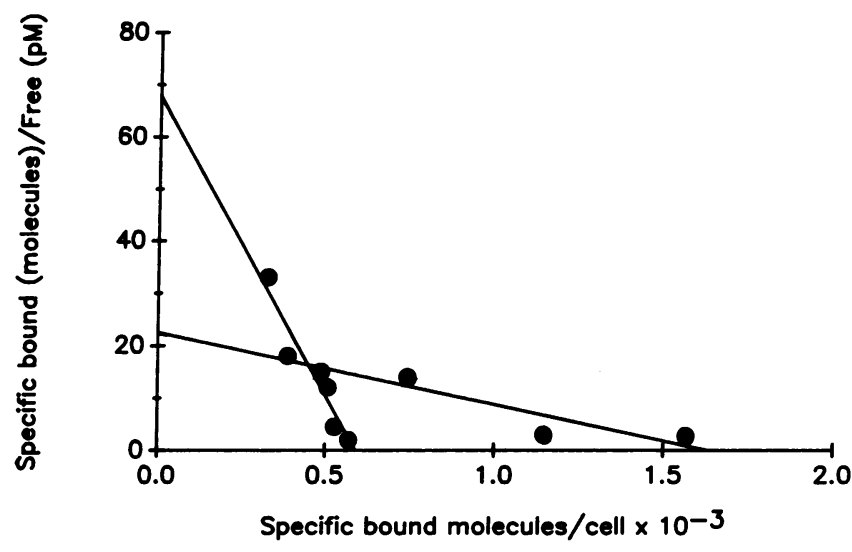

Figure 2. Typical Scatchard analysis of intermediate and high affinity IL-2R expression on PHA-stimulated lymphocytes from a patient with a glioblastoma. See Fig. 1 for details.

II) suggest that although there is variability among both populations of cells, the $T$ cells obtained from patients and normals appear to express similar steady state levels of mRNA for p55. Moreover, there does not appear to be any significant differences in the ratio of the two major mRNA species $(3.5 / 1.5 \mathrm{~kb})$.

Posttranslational processing of the 555 gene product. Because there does not appear to be a defect in the transcription of the gene for p55, it was of interest to determine if the decreased expression of this protein on the surface of activated $T$ cells from patients was the result of a defect in the posttranslational modification of $\mathrm{p} 55$. The primary translation product of the p55 mRNA is a $34-\mathrm{kD}$ peptide (p34) (24). Cleavage of a signal peptide results in the formation of a $33-\mathrm{kD}$ peptide that is evident at early time points. Cotranslational addition of $\mathrm{NH}_{2}$-linked oligosaccharides yields two more precursor peptides $\mathrm{p} 35$ and $\mathrm{p} 37$. The $\mathrm{p} 35 / \mathrm{p} 37$ precursors are further pro-
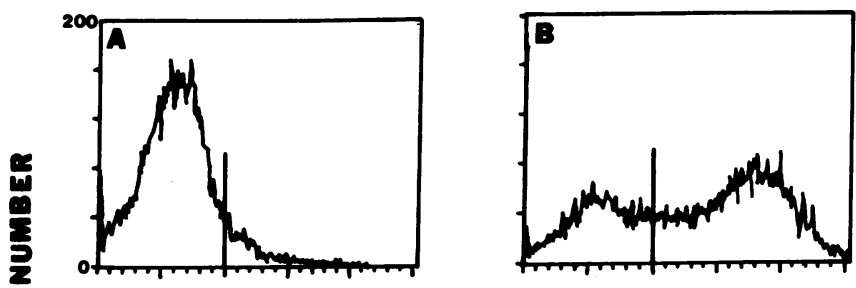

담
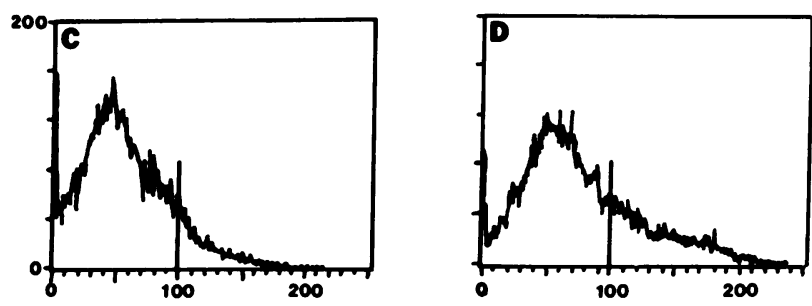

FLUORESCENT INTENSITY

Figure 3. Typical immunofluorescent profiles of 48-h PHA-stimulated lymphocytes from a normal individual $(A$ and $B)$ and a patient with a glioblastoma $(C$ and $D$ ) stained with anti-TAC monoclonal antibody $(B$ and $D)$ and an irrelevant monoclonal antibody ( $A$ and $C)$, as described in Methods. 


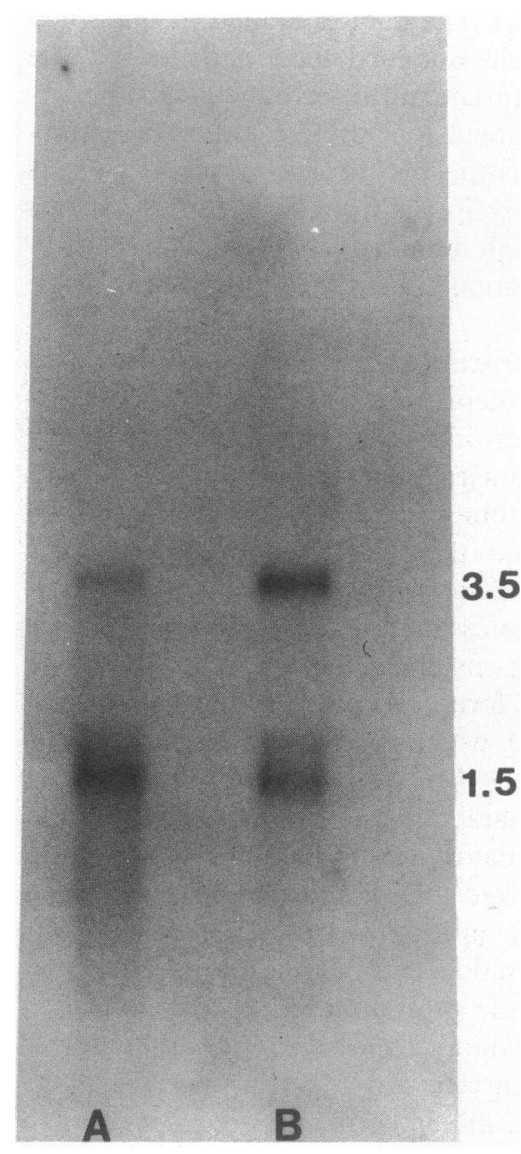

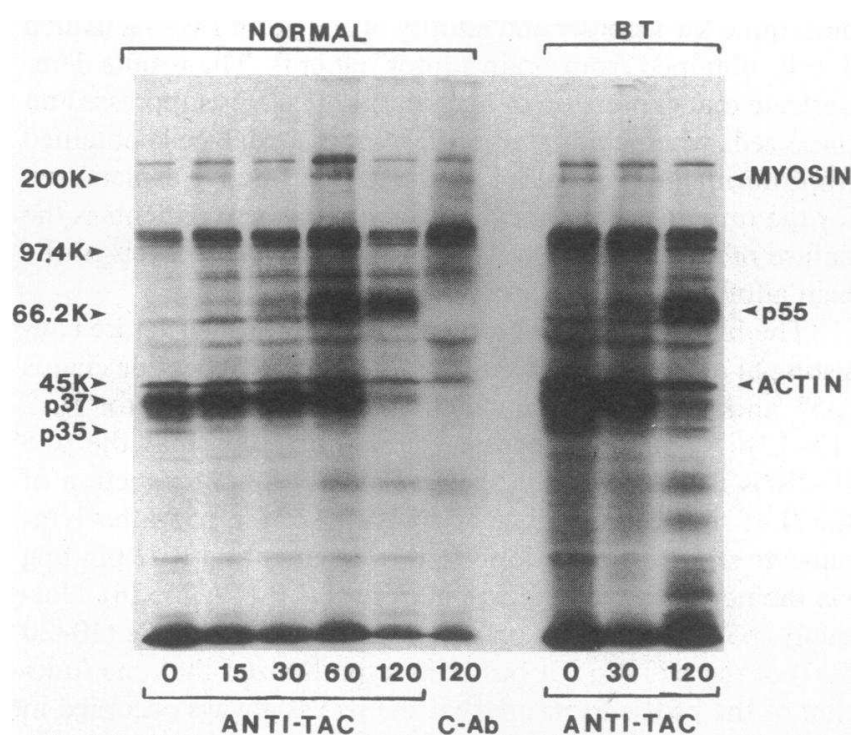

Figure 4. IL-2 R mRNA (p55) expression in PHA-stimulated

1.5 T cells obtained from a normal individual (lane $A)$ and a patient with a glioblastoma (lane $B$ ). The RNAs were electrophoresed on formaldehyde/agarose gels, transferred to nitocellulose, and hybridized with ${ }^{32}$ P-labeled pIL2R2 cDNA.

cessed in the Golgi through p37 to the mature p55 by the addition of $O$-linked carbohydrates and sialic acid (24).

$\left[{ }^{35}\right.$ S]Methionine pulse-chase experiments were performed on PHA-activated T cells from normal individuals and brain tumor patients to determine if there were any difference in the posttranslational processing of $\mathrm{p} 55$, which might account for its decreased expression on the cell surface. Radiolabeled proteins were specifically immunoprecipitated with anti-Tac MAb and analyzed by SDS-PAGE (Fig. 5). After 0 and 15 min

Table II. Northern Blot Analysis of Total RNA Extracted from Activated T Cells from Normal Individuals and Patients with Brain Tumors

\begin{tabular}{lccl}
\hline Cell source & $3.5 \mathrm{mRNA}^{*}$ & $1.5 \mathrm{mRNA}$ & $3.5 / 1.5$ \\
\hline Normal 1 & 0.154 & 0.373 & 0.413 \\
Patient 1 & 0.624 & 0.492 & 01.27 \\
Normal 2 & 0.677 & 0.535 & 1.26 \\
Patient 2 & 0.486 & 0.337 & 1.39 \\
Normal 3 & 0.191 & 0.080 & 2.39 \\
Patient 3 & 0.368 & 0.293 & 1.25 \\
Normal 4 & 0.781 & 0.702 & 1.11 \\
Patient 4 & 0.550 & 0.400 & 1.38 \\
Patient 5 & 0.547 & 0.287 & 1.64 \\
\hline
\end{tabular}

* The OD values for p55 mRNA obtained from Visage 2000 Bioimage Analyzer were compared to OD values obtained for 18s rRNA and expressed as the ratio of p55 mRNA to $18 \mathrm{~s}$ rRNA per lane.

Figure 5. Pulse-chase studies of PHA-activated PBL from normal individuals (left) and brain tumor patients (right). Precipitations were done with either anti-Tac or control anti-coronavirus (C-Ab) monoclonal antibodies. Time of chase in minutes is on the abscissa and molecular weight markers on the ordinate. Locations of $\mathrm{p} 35, \mathrm{p} 37$, and p55 are marked.

of chase with unlabeled methionine, anti-Tac MAb immunoprecipitated the $p 35$ and $p 37$ precursor peptides in cell extracts from normal individuals. Extending the chase period to 30 min results in the movement of label from the p35 precursor to the p37 precursor. By 60 min label is detected in the mature p55 and by $120 \mathrm{~min}$ all the label is concentrated in the mature p55. Analysis of immunoprecipitates of cell extracts from brain tumor patients 0,60 , and $120 \mathrm{~min}$ after chase with unlabeled methionine are presented in lanes 8,9 , and 10 of Fig. 5 . These results are identical to those obtained with PHA-activated $\mathrm{T}$ cells from normal individuals with the appearance of normal levels of p55 protein by $120 \mathrm{~min}$.

\section{Discussion}

The immunologic status of patients with primary malignant brain tumors is characterized by an impairment of lymphocyte activation (1-9). Previously we have reported the presence of an intrinsic anomaly in $T$ cells obtained from patients harboring malignant brain tumors resulting in diminished responsiveness and failure to move out of the $G_{1}$ phase of the proliferative cell cycle (10). Moreover, the $T$ cell hyporesponsiveness is confined to the $T$ helper cell (CD4) and results, in part, from the inability of these cells to secrete IL-2 (10). More recently, we have shown that the addition of IL-2 to PHA-stimulated PBL from brain tumor patients does not restore their proliferative levels to normal values, suggesting a defect in the expression of the IL-2R (12). Indeed, the number of Tac-positive cells is less than normal throughout all periods of mitogen stimulation. The recent findings of the role of high-affinity IL-2R in providing proliferative signals for lymphocyte transformation raised the question of whether mitogen-stimulated $T$ cells obtained from these patients were capable of assembling normal levels of high affinity IL-2R. In the present study, we have utilized the specific binding of radiolabeled IL-2 to 
determine the number and affinity of IL-2R on PHA-activated $T$ cells obtained from brain tumor patients. The results demonstrate that expression of high affinity IL-2R is suppressed on these cells when compared to PHA-activated T cells obtained from normal individuals. Therefore, an attractive explanation for the impaired lymphocyte reactivity of these patients is the failure of stimulated $T$ cells to express sufficient levels of the high affinity IL-2R required for proliferation.

The high affinity IL-2 receptor is a complex structure consisting of at least two noncovalently linked polypeptide chains (p55 and p75), both of which have binding sites for IL-2 (13-17). Although, recent evidence indicates that the p75 IL-2R is the biologically relevant moiety for transduction of the IL-2 signal, the induced expression of the p 55 after lymphocyte stimulation is important in augmenting IL-2 binding via the newly assembled high affinity $\operatorname{IL}-2 \mathrm{R}(19,25,26)$. Normally, p55 is expressed on activated $T$ cells in excess (10-20 fold) of the p75 (26). It has been hypothesized that one function of the p55 is to insure that the p75 is always occupied in the formation of the functional high affinity IL-2R (26). In our studies, the relative density of the p55 as measured by flow cytometry using anti-TAC MAb is significantly less on activated $T$ cells from patients with brain tumors when compared to similarly treated cells from normal individuals. Moreover, the intermediate affinity $p 75$ IL-2R is always expressed in excess (greater than threefold) of the high affinity IL-2R on activated lymphocytes obtained from patients with brain tumors. Collectively, these data suggest that mitogen-stimulated $T$ cells obtained from patients with malignant gliomas express lower levels of the functional high affinity IL-2R principally because they have insufficient levels of p55 available for association with p75.

The explanation for diminished p55 expression after lectin stimulation remains to be elucidated. It is evident, however, that altered $\mathrm{T}$ cell responsiveness of patients with gliomas is linked to abnormal IL-2R formation and expression. However, the earliest events of mitogen-induced lymphocyte activation required for the development of competency to begin the proliferative cycle, e.g., lectin binding, phosphoinositide hydrolysis and protein kinase $\mathrm{C}$ translocation, occur normally in $\mathrm{T}$ cells obtained from brain tumor patients (unpublished observations). It may be hypothesized that the failure to express p55 and hence inability to assemble high-affinity IL-2R required for proliferation stems from defects in regulation of IL-2R gene transcription and/or translation. However, Northern blot analysis of total RNA extracted from activated $T$ cells obtained from patients with brain tumors indicates that these cells express normal steady-state levels of mRNA for p55. Leonard et al. (27) have noted a predominance of the 3.5-kb species in cells that express low levels of IL-2R. They suggest that, although both species code for protein, the $1.5-\mathrm{kb}$ species may be the one that varies with the magnitude of IL-2R expression. This does not appear to be the case in our system. The ratio of 3.5/1.5 mRNA is similar for cells obtained from patients and normal individuals.

The primary translation product of the mRNA for p55 is a peptide with a molecular weight of $34 \mathrm{kD}$ (p34), which undergoes extensive post-translational modification to yield the final protein product of $55 \mathrm{kD}(24)$. All the precursor peptides except p34 bind IL-2, thus, these extensive posttranslation modifications do not appear to be essential to ligand binding. However, these modifications may alter the affinity with which the p55 IL-2R binds IL-2 (24). The data presented in this study with PHA-activated T cells obtained from patients indicate that mRNA for p55 is translated into a product which undergoes normal post-translational processing resulting in synthesis of normal levels of mature p55 protein. Thus, it appears that the failure of activated $T$ cells from brain tumor patients to assemble functional high affinity IL-2R can not be attributed to defects in transcription of the gene or translation of the mRNA that code for p55.

These data do not correlate with the observed decreased expression of the Tac protein on activated $T$ cells from patients. There are a number of possible explanations that may account for these discrepancies. First, p55 may be degraded in lymphocytes from brain tumor patients before it is expressed on the cell surface. Second, there is evidence $(28,29)$ that $T$ cell lines, as well as mitogen-activated lymphocytes from normal individuals, which express mature p55 on their cell surface also release measurable levels of this protein into the culture supernatant. The secreted form demonstrates an apparent molecular mass of $45-50 \mathrm{kD}$, which is smaller than the p55 surface receptor on these cells. Thus, the release of soluble p55 IL-2R appears to be a characteristic of $T$ cell activation and may play an immunoregulatory role in lymphocyte activation (28). It may be hypothesized that this normal process of p55 IL-2R secretion has been upregulated in activated lymphocytes from patients, thus reducing the levels of this protein on the cell surface. Finally, the glioma may be secreting factors, which, in some unknown manner mask or prevent the expression of p55 on the cell surface and prevent assembly of the functional high affinity IL-2R. Experiments are in progress to test these possibilities.

The results of the present study provide insights into the potential therapeutic role of lymphokine-activated killer cells (LAK-cell), cytotoxic T lymphocytes (CTL) and/or IL-2 infusion, as well as into the immunobiologic relationship between glioma cells and lymphocytes. In vitro, high doses of IL-2 promote the growth and expansion of LAK cells obtained from these patients yet the numbers are greatly reduced when compared with healthy controls (30-32). Glioma specific CTL also may be isolated from tumor tissue but are exceedingly low in their proliferative response to IL-2 (32-34). Moreover, tumor infiltrating lymphocytes that are positive for a variety of $T$ cell markers do not express the p55 IL-2R (33). Hence the inability of lymphocytes obtained from these patients to express functional high-affinity IL-2R offers one explantation for the limited inducible expansion of these IL-2-dependent lymphocyte subpopulations as well as the relative ineffectiveness of LAK cells and/or IL-2 in treating patients with malignant gliomas $(35,36)$.

The relationship between the presence of a malignant brain tumor and alterations in intrinsic lymphocyte function as demonstrated in this and previous investigations remains conjectural. Previously, we (37) and others (38-40) have demonstrated that glioma cells secrete a factor(s) capable of modulating lymphocyte proliferative responsiveness. These factors suppress the responsiveness of $T$ cells obtained from both patients with brain tumors as well as normal individuals. Recent evidence indicates that glioma suppressor factor(s) impair reactivity of $T$ cells obtained from healthy individuals by modulation of the expression of the high affinity IL-2R (unpublished observation); a finding similar to that observed in $\mathrm{T}$ cells obtained from patients with gliomas. How this abrogation of 
IL-2R assembly and/or expression is affected is conjectural. Nonetheless, it is tempting to postulate that broad suppression of immune responsiveness in glioma patients results from an interaction between glioma suppressive factor and circulating $T$ cells, which modifies the ability these cells to express the functional high affinity IL-2R.

\section{Acknowledgments}

We would like to thank Dr. Warner C. Greene, Duke Univ., for kindly providing the cDNA clone pIL2R2 and Dr. Thomas Waldman, National Institutes of Health, for the gift of anti-TAC MAb. We thank Angie Hardin for preparing this manuscript. We also thank Karen Pollok and Dr. Vincent O'Brien for their critique of this manuscript.

This research was supported by National Institutes of Health grant CA-18234.

\section{References}

1. Brooks, W. H., M. G. Netsky, D. A. Horwitz, and D. E. Normansell. 1972. Cell-mediated immunity in patients with primary brain tumors. J. Exp. Med. 136:1631-1747.

2. Brooks, W. H., T. L. Roszman, and A. S. Rogers. 1976. Impairment of rosette-forming $\mathrm{T}$ lymphocytes in patients with primary intracranial tumors. Cancer. 37:1869-1973.

3. Brooks, W. H., T. L. Roszman, M. S. Mahaley, and R. Woosley. 1977. Immunobiology of primary intracranial tumors. II. Analysis of lymphocyte populations in patients with primary brain tumors. Clin. Exp. Immunol. 29:61-66.

4. Young, H. R., R. Sakala, and A. M. Kaplan. 1986. Inhibition of cell mediated immunity in patients with brain tumors. Surg. Neurol. 5:19-23.

5. Mahaley, M. S., W. H. Brooks, T. L. Roszman, D. D. Bigner, L. Duka, and S. Richardson. 1977. Immunobiology of primary intracranial tumors. I. Studies of the cellular and humoral general immune competence of brain-tumor patients. J. Neurosurg. 46:467-476.

6. Levy, N. L. 1978. Cell-mediated cytotoxicity and serum-mediated blocking: evidence that their associated determinants on human tumor cells are different. J. Immunol. 121:916-922.

7. Roszman, T. L., and W. H. Brooks. 1980. Immunobiology of primary intracranial tumors. III. Demonstration of a qualitative lymphocyte abnormality in patients with primary brain tumors. Clin. Exp. Immunol. 39:395-402.

8. Braun, O. P., R. O. Penn, A. M. Flannery, and J. E. Harris. 1982. Immunoregulatory cell function in peripheral blood leukocytes of patients with intracranial gliomas. Neurosurgery. 10:203-209.

9. Wood, G. W., and R. A. Morantz. 1982. In vitro reversal of depressed $\mathrm{T}$ lymphocyte function in the peripheral blood of brain tumor patients. J. Natl. Cancer Inst. 68:27-33.

10. Elliott, L. H., T. L. Roszman, and W. H. Brooks. 1984. Cytokinetic basis for the impaired activation of lymphocytes from patients with primary intracranial tumors. J. Immunol. 132:1208-1215.

11. Roszman, T. L., W. H. Brooks, and L. H. Elliott. 1982. Immunobiology of primary intracranial tumors. VI. Suppressor cell function and lectin-binding lymphocyte subpopulations in patients with cerebral tumors. Cancer. 50:1273-1279.

12. Elliott, L., W. Brooks, and T. Roszman. 1982. Role of interleukin-2 (IL-2) and IL-2 receptor expression in the proliferative defect observed in mitogen-stimulated lymphocytes from patients with brain gliomas. J. Natl. Cancer Inst. 78:919-922.

13. Sharon, M. R., R. D. Klausner, B. R. Cullen, R. Chizzonite, and W. J. Leonard. 1986. Novel interleukin-2 receptor subunit detected by cross-linking under high-affinity conditions. Science (Wash. DC). 234:859-863.

14. Teshigawara, K., H. M. Wang, K. Kato, and K. A. Smith. 1987.
Interleukin 2 high-affinity receptor expression requires two distinct binding proteins. J. Exp. Med. 165:223-238.

15. Tsudo, M., R. W. Kozak, C. K. Goldman, and T. A. Waldmann. 1986. Demonstration of a non-Tac peptide that binds interleukin 2: A potential participant in a multichain interleukin 2 receptor complex. Proc. Natl. Acad. Sci. USA. 83:9694-9698.

16. Dukovich, M., Y. Wano, Le Thi Bich Thuy, P. Katz, B. R Cullen, J. H. Kehrl, and W. C. Greene. 1987. A second human interleukin-2 binding protein that may be component of high affinity interleukin-2 receptors. Nature (Lond.). 327:518-522.

17. Robb, R. J., C. M. Rusk, J. Yodoi, and W. C. Greene. 1987. Interleukin 2 binding molecule distinct from the Tac protein: Analysis of its role in formation of high affinity receptors. Proc. Natl. Acad. Sci. USA. 84:2002-2176.

18. Saragovi, H., and T. R. Malek. 1987. The murine interleukin-2 receptor: Irreversible cross-linking of radiolabeled interleukin-2 to high affinity interleukin-2 receptors reveals a noncovalently associated subunit. J. Immunol. 139:1918-1926.

19. Bich-Thuy, L. T., M. Dukovich, N. J. Peffer, A. S. Fauci, J. H. Kehrl, and W. C. Greene. 1987. Direct activation of human resting T cells by IL-2: The role of an IL-2 receptor distinct from the TAC protein. J. Immunol. 139:1550-1556.

20. Boyum, A. 1968. Isolation of mononuclear cells and granulocytes from human blood. Isolation of mononuclear cells by one centrifugation and of granulocytes by combining centrifugation and sedimentation at 1 g. Scand. J. Clin. Invest. 21(Suppl. 97):110.

21. Robb, R. J., W. C. Greene, and C. M. Rusk. 1984. Low and high affinity cellular receptors for interleukin 2. J. Exp. Med. 160:1126-1146.

22. Chirgwin, J. M., A. E. Pryubyla, R. J. MacDonald, and W. J. Rutter. 1979. Isolation of biologically active ribonucleic acid from sources enriched in ribonuclease. Biochemistry. 18:5294-5299.

23. Davies, A. A., and M. H. Brown. 1987. Biochemical characterization of lymphocyte surface antigens. In Lymphocytes: a Practical Approach. G. G. B. Klaus, editor. IRL Press, Oxford and Washington DC. $236-238$.

24. Leonard, W. J., J. M. Depper, M. Kronke, R. J. Robb, T. A. Waldman, and W. C. Greene. 1985. The human receptor for T-cell growth factor. Evidence for variable post-translational processing, phosphorylation, sulfation, and the ability of precursor forms of the receptor to bind T-cell growth factor. J. Biol. Chem. 260:1872-1880.

25. Robb, R. J., and W. C. Greene. 1987. Internalization of interleukin 2 is mediated by B chain of the high-affinity interleukin 2 receptor. J. Exp. Med. 165:1201-1206.

26. Smith, K. A. 1988. The interleukin 2 receptor. Adv. Immunol. 42:165-179.

27. Leonard, W. L., M. Kronke, N. J. Peffer, J. M. Depper, and W. C. Greene. 1985. Interleukin 2 receptor gene expression in normal human T lymphocytes. Proc. Natl. Acad. Sci. USA 82:6281-6285.

28. Rubin, L. A., C. C. Kurman, M. E. Fritz, W. E. Biddison, B. Boutin, R. Yarchoan, and D. L. Nelson. 1985. Souble interleukin 2 receptors are released from activated human lymphoid cells in vitro. $J$. Immunol. 135:3172-3177.

29. Nelson, D. L., L. A. Rubin, C. C. Kurman, M. E. Fritz, and B. Boutin. 1986. An analysis of the cellular requirements for the production of soluble interleukin-2 receptors in vitro. J. Clin. Immunol. 6:114-120.

30. Jacob, S. K., D. J. Wilson, P. L. Kornblith, and E. A. Grimm. 1986. In vitro killing of human glioblastoma by interleukin-2 activated autologous lymphocytes. J. Neurosurg. 65:114-117.

31. Whiteside, T. L., Y. L. Wang, R. G. Selker, and R. B. Herberman. 1988. In vitro generation and antitumor activity of adherant lymphokine-activated killer cells from the blood of patients with brain tumors. Cancer Res. 48:6069-6075.

32. Kuppner, M. C., M. F. Hamou, and N. De Tribolet. 1988 Immunohistological and functional analyses of lymphoid infiltrates in human glioblastomas. Cancer Res. 48:6926-6932.

33. Miescher, S., T. L. Whiteside, N. De Tribolet, and V. V. 
Fliedner. 1988. In situ characterization, clonogenic potential, and antitumor cytolytic activity of $\mathrm{T}$ lymphocytes infiltrating human brain cancers. J. Neurosurg. 68:438-448.

34. Sawamura, Y., H. Abe, T. Aida, M. Hosokawa, and H. Kobayashi. 1988. Isolation and in vitro growth of glioma-infiltrating lymphocytes, and an analysis of their surface phenotypes. J. Neurosurg. 69:745-750.

35. Merchant, R. E., A. J. Grant, L. H. Merchant, and H. F. Young 1988. Adoptive immunotherapy for recurrent glioblastoma multiforme using lymphokine activated killer cells and recombinant interleukin-2. Cancer. 62:665-671.

36. Jacobs, S. K., D. J. Wilson, P. L. Kornblith, and E. A. Grimm. 1986. Interleukin-2 and autologous lymphokine-activated killer cells in the treatment of malignant glioma. J. Neurosurg. 64:743-749.
37. Roszman, T. L., W. H. Brooks, and L. H. Elliott. 1987. Inhibition of lymphocyte responsiveness by a glial tumor cell-derived suppressive factor. J. Neurosurg. 67:874-879.

38. Fontana, A., H. Hengartner, N. de Tribolet, and E. Weber. 1984. Glioblastoma cells release interleukin 1 and factors inhibiting interleukin 2-mediated effects. J. Immunol. 132:1837-1844.

39. Rutka, J. T., M. L. Rosenblum, R. Stern, H. J. Ralston, D. Dougherty, and S. De Armond. 1989. Isolation and partial purification of growth factors with TGF-like activity from human malignant gliomas. J. Neurosurg. 71:875-883.

40. Kuppner, M. C., M. F. Hamou, Y. Sawamura, and N. De Tribolet. 1989. Inhibition of lymphocyte function by glioblastoma derived transforming growth factor. J. Neurosurg. 71:211-217. 